CADERNO DE POESIAS II

Érica Antunes ${ }^{1}$

ÊXODO

São três promessas em cena,

vitrines de tantas partidas.

Dela, o colo alimenta,

Dele, o ombro abriga,

a cria, o sonho, a fé, a família.

Entre as caixas e as trouxas,

nasce de terra um sapato:

Calça os pés e roça a vida.

VÍCIO

Um bêbado cai na calçada

e a menina que com a mãe passa

descobre que o urso que abraça

é uma garrafa de pinga. 


\section{INFÂNCIA POBRE}

O céu da boca

é uma noite

estrelada de cáries.

\section{O CÉU}

A mãe da Patrícia estourava pipocas

sem tampar a panela

e a gente achava

a coisa mais linda do mundo.

Eram fogos espocando

no céu da nossa infância.

\section{TANTO CIÚME}

Farta da rima pobre

dos cabelos descoloridos,

comprou

um bico-de-pena

e tingiu de nanquim

a VIDA. 


\section{(EN)FADO}

O açúcar em cor

de rosa tinge

a vida

e dissolve

aos poucos

o solitário cinza.

\section{ROTINA}

esbarra a fome

no torturante

pão de cada dia.

\section{DESFRUTOS}

Plantou

o NADA

e colheu

o VAZIO

da espera

do quase dia

da quase noite

entre o verão

e a primavera. 


\section{DISPARATE}

Foge a fome

na meia diária

que o bar da esquina

come na média

mais duas coxinhas.

\section{O BIGODE DO MEU PAI}

Meu pai era feio,

Feio e tão magro...

Carinha de menino.

Guando criou pêlos na cara,

Namorou minha mãe.

... tão bonita ela!

Noivou,

Casou.

“... mas na Quaresma, meu Deus?!”

“... será que ela está grávida?”

Não, era moça direita.

Casou virgem, sim senhor...

De lá pra cá restou a foto:

Só vejo o bigode! 


\section{EFEMÉRIDES}

Entre rusgas

e rugas

mora

a fúria

(in)contida

dos afetos.

${ }_{1}$ Érica Antunes é doutoranda do Programa de Pós-Graduação em Estudos Comparados de Literaturas de Língua Portuguesa da Universidade de São Paulo (USP) e bolsista da Fundação de Amparo à Pesquisa do Estado de São Paulo (FAPESP). E-mail: erica.antunes@gmail.com. 